\title{
Samfélagsábyrgð í íslenskum skaðatryggingafélögum
}

Harpa Dís Jónsdóttir, Lára Jóhannsdóttir og Snjólfur Ólafsson ${ }^{1}$

\section{Ágrip}

Við hrun bankakerfisins á Íslandi haustið 2008 var háværum mótmælum beint að Alpingi, viðskiptalífinu og ráðamönnum í stjórnsýslunni. Margir settu fram kröfur um að peir sem væru ábyrgir fyrir hruninu öxluðu ábyrgð og svöruðu til saka. Kallað var eftir nýjum gildum, nýjum viðskiptaháttum og framtíðarsýn með aukna ábyrgð að leiðarljósi. Aukin krafa kom einnig fram um að árangur samfélagsábyrgðar skyldi mældur á einhvern hátt og birtur hagsmunaaðilum.

Í pessari grein verður greint frá helstu niðurstöðum rannsóknar sem hefur pað að markmiði að fjalla um fjögur íslensk skaðatryggingafélög, pað hvernig pau hafa brugðist við kallinu um aukna samfélagsábyrgð, áherslur peirra á pví sviði og innleiðingu aðgerða. Heimasíður félaganna voru skoðaðar með tilliti til samfélagsábyrgðar, hvort og pá á hvaða hátt félögin starfa á samfélagslega ábyrgan hátt, hvort pau hafa gengist undir formlegar skuldbindingar á pessu sviði og hvernig pau birta hagsmunaaðilum upplýsingar um samfélagsábyrgð sína. Pá voru tekin viðtöl við einstaklinga innan félaganna sem hafa með samfélagsmál að gera. Spurt var m.a. hvort og pá á hvaða hátt félögin sinntu samfélagsábyrgð, hver væri helsti hvatinn til aðgerða og hverjar helstu áskoranir væru við innleiðingu.

Rannsóknin leiðir í ljós að félögin fjögur eru öll að vinna að pví að innleiða samfélagslega ábyrgð, en eru pó komin fremur skammt á veg sé horft til skilgreininga á pví hvað samfélagsábyrgð felur í sér. Tvö félaganna hafa sett sér stefnu um samfélagsábyrgð en hin tvö áætla að setja sér slíka stefnu. Viðmælendur nefna flestir forvarnir og endurvinnslu pegar spurt var um áherslur á sviði samfélagsábyrgðar, en einnig styrki og stuðning við ýmis samfélagsleg verkefni. Helsta áskorunin við innleiðingu samfélagsábyrgðar er að mati viðmælenda tímaskortur og smæð félaganna. Fræðilegt gildi rannsóknarinnar felst í að varpa ljósi á orðræðu sem ríkjandi er í greininni, en sú orðræða er studd upplýsingum af vefsíðum vátryggingafélaganna. Orðræðan gefur mynd af stöðu samfélagsábyrgðar hjá stóru íslensku skaðatryggingafélögunum, en takmarkaðar rannsóknir á skaðatryggingafélögunum liggja fyrir á pessi sviði. Hagnýtt gildi rannsóknarinnar felst í stöðumati sem skaðatryggingafélögin geta horft til við áframhaldandi innleiðingu samfélagsábyrgðar í eigin rekstri.

\footnotetext{
${ }^{1}$ Harpa Dís Jónsdóttir, verkefnisstjóri Háskóla Íslands, Lára Jóhannsdóttir, lektor, Viðskiptafræðideild Háskóla Íslands, Snjólfur Ólafsson, prófessor, Viðskiptafræðideild Háskóla Íslands. Höfundar færa viðmælendum sínum bestu pakkir fyrir pátttökuna.
} 


\begin{abstract}
The demand for increased corporate social responsibility (CSR) has become more intense worldwide in recent years. After the collapse of the Icelandic banking system in the autumn of 2008, there were protests against the Parliament, the business sector and the government, demanding that those liable for the situation assumed responsibility for their actions or be taken to court. The public requested new values for business practices and increased responsibility. Additionally, the demand was to measure and disclose corporate responsibility performance.

The aim of this study is to look at how four Icelandic non-life insurance companies have responded to the call for increased emphasis on corporate social responsibility, their strategies and how they are implemented. To reach our goal the insurance company websites were examined for CSR themes. In particular we looked for examples on whether and in what way the companies operate in accordance with CSR, whether they have formally committed to CSR, and how they disclose information to stakeholders. Additionally, interviews were carried out with executives and specialists within the insurance companies. They were asked about their companies' CSR emphasis, drivers behind actions and the main implementation challenges.

The study reveals that all four insurance companies place some emphasis on CSR, but have made limited progress when compared to what definitions of CSR comprise. Two of the companies have adopted CSR strategies, while the other two companies are planning to do so. Actions brought up as examples by interviewees included loss prevention and recycling initiatives, grants and support to various community projects. The main barriers to implementation identified were company size and time constraints. The theoretical value of the study is a better understanding of the first steps of CSR implementation in insurance companies and the discourse related to CSR within the companies, but limited research on non-life insurance companies is available in this field. The practical value of the study lies in the status assessment which non-life insurance companies can look to in the continued implementation of social responsibility in their operations.
\end{abstract}

JEL flokkun: D22, M1, M14

Lykilorð: Samfélagsábyrgð, skaðatryggingafélög, stefna 


\section{Inngangur}

Krafan um að fyrirtæki axli ábyrgð á áhrifum sínum á samfélag og umhverfi hefur verið til staðar um langt árabil (Hoffman, 2000). Efnahagshrunið árið 2008 hefur haft áhrif á aðgerðir ýmissa fyrirtækja á sviði samfélagsábyrgðar vegna prýstings sem pau urðu fyrir, m.a. vegna fjöldauppsagna sem gripið var til og niðurskurðar til samfélagslegra verkefna. Sumar aðgerðir fyrirtækja í kjölfar hrunsins eru álitnar jákvæðar, en par má nefna auknar áherslur á góða stjórnarhætti sem og umhverfis- og starfskjarastefnu (Jacob, 2012). Prátt fyrir efnahagslega niðursveiflu pá hefur pað komið í ljós í stjórnendakönnun Boston Consulting Group og MIT Sloan Management Review að skuldbinding fyrirtækja og fjárfestingar á sviði sjálfbærni hafi aukist eftir hrun, öfugt við pað sem mátt hefði ætla (Haanaes o.fl., 2011). Kröfur um að fyrirtæki stuðli að sjálfbærri nýtingu náttúruauðlinda, fjárfesti í samfélagslega ábyrgum verkefnum og að pau komi fram við starfsmenn og samfélagið í heild á sanngjarnan og réttlátan hátt verða sífellt meira áberandi (Jones, 2012). Pessi prýstingur endurspeglast t.d. í alpjóðasamningum á sviði umhverfismála, löggjöf og prýstingi frá ýmsum hagsmunaöflum sem kalla eftir nýjum gildum, nýjum viðskiptaháttum og nýrri framtíðarsýn með aukna ábyrgð að leiðarljósi (Hoffman, 2000). ISO 26000 staðallinn um samfélagslega ábyrgð sem kom út árið 2010 er ein birtingarmynd aukins prýstings á fyrirtæki um að pau axli ábyrgð.

Krafa um að árangur samfélagsábyrgðar sé mældur og niðurstöður birtar hagsmunaaðilum eykst einnig (Rose, 2013), sérstaklega meðal stærri fyrirtækja. Evrópusambandið lögfesti til að mynda árið 2014 pá kröfu að stærri fyrirtæki skuli upplýsa um atriði, önnur en fjárhagslegs eðlis, p.e. atriði sem lúta að starfsmönnum, umhverfi og samfélagi. Löggjöfin tekur bæði til einkafyrirtækja og opinberra fyrirtækja (Council of the European Union, 2014). Hér á landi hefur áhersla á samfélagsábyrgð einnig aukist á undanförnum árum (t.d. Dagný Arnarsdóttir, 2009; Dagný Kaldal Leifsdóttir, 2013; Julia Vol, 2012; Lára Jóhannsdóttir, Snjólfur Ólafsson og Harpa Dís Jónsdóttir, 2015; Snjólfur Ólafsson, Brynhildur Davíðsdóttir og Lára Jóhannsdóttir, 2014).

Skaðatryggingafélög gegna mikilvægu samfélagslegu hlutverki með starfsemi sinni, m.a. með pví að tryggja verðmæti, koma í veg fyrir tjón og bæta tjón, ásamt pví að stunda fjárfestingar og að vera vinnuveitendur. Рað hefur sýnt sig að íslensk skaðatryggingafélög eru eftirbátar vátryggingafélaga í Danmörku, Finnlandi, Noregi og Svípjóð pegar kemur að umhverfislegum áherslum í rekstri (Lára Jóhannsdóttir, 2014). Pví er pað gagnlegt í fræðilegu og hagnýtu tilliti að skoða víðari áherslur en umhverfisábyrgð hjá hérlendum skaðatryggingafélögum, enda hafa fáar rannsóknir verið gerðar á pví sviði til pessa ef frá eru taldar doktorsrannsókn Láru Jóhannsdóttur (2012) sem ber yfirskriftina Áhugi og framlag norrænna skaðatryggingafélaga á úrlausn umhverfislegra vandamála og BA ritgerð Braga Skaftasonar (2014) sem ber yfirskriftina Samfélagsábyrgð tryggingafélaga: Siðareglur og siðferðisleg álitamál (Bragi Skaftason, 2014). Pá hefur pað komið fram að vitund og viðhorf stjórnenda innan vátryggingafélaga getur haft áhrif á aðgerðir eða aðgerðaleysi á sviði umhverfisábyrgðar (Lára Jóhannsdóttir, Snjólfur Ólafsson og Brynhildur Davíðsdóttir, 2013).

Til vátryggingafélaga teljast bæði líf- og skaðatryggingafélög. Í pessari rannsókn var einungis horft til stöðu mála hjá stærstu skaðatryggingafélögum á Íslandi, en pau tryggja m.a. fasteignir, bifreiðar og lausafé auk pess að bjóða vernd gegn ábyrgðartjónum (Samtök fjármálafyrirtækja, e.d. c). Félögin sem tekin eru til skoðunar í pessari grein eru Sjóvá, Tryggingamiðstöðin (TM), Vátryggingafélag Íslands (VÍS) og Vörður. Markmiðið er að skoða áherslur peirra á sviði samfélagsábyrgðar, stefnu og framkvæmd hennar og helstu áherslur og hindranir við innleiðingu. Leitað er svara við eftirfarandi rannsóknarspurningum, en búið er 
að leita svara við peim út frá umhverfisábyrgð fyrirtækja (Lára Jóhannsdóttir, 2012), en ekki út frá samfélagsábyrgð fyrirtækja:

1. Hver er stefna skaðatryggingafélaganna varðandi samfélagsábyrgð?

2. Hverjir eru helstu hvatar skaðatryggingafélaganna til pess að innleiða samfélagsábyrgð?

3. Hverjar eru helstu áherslur skaðatryggingafélaganna við innleiðingu á samfélagsábyrgð?

4. Hver er helsti ávinningur pess að innleiða samfélagsábyrgð að mati viðmælanda?

5. Hverjar eru helstu hindranir við innleiðingu á samfélagsábyrgð skaðatryggingafélaganna?

Niðurstöðurnar byggjast á viðtölum við forsvarsmenn félaganna, en viðtölin fóru fram vorið 2014, sem og á upplýsingum af heimasíðum félaganna. Greinin er pannig upp byggð að í kafla 2 er fjallað um samfélagsábyrgð fyrirtækja. Kafli 3 fjallar um hlutverk skaðatryggingafélaga. Gerð er grein fyrir rannsóknaraðferðum í kafla 4 og helstu niðurstöðum í kafla 5. Umræður um niðurstöðurnar má finna í kafla 6.

\section{Samfélagsábyrgð fyrirtækja}

Líta má aftur til iðnbyltingarinnar á 18. öld og samfélagspróunar sem pá átti sér stað, eða jafnvel lengra aftur, pegar rætt er um ábyrgð fyrirtækja (Blowfield og Murray, 2014). Kenningar um ábyrgð fyrirtækja snerust í fyrstu um ábyrgð stjórnenda fyrirtækja, en próuðust síðar yfir í kenningar par sem meira er fjallað um ábyrgð fyrirtækja sem stofnana (Berle og fl., 1932; Davis, 1973). Einn af virtustu fræðimönnum á sviði samfélagsábyrgðar fyrirtækja, Archie B. Carroll, tilgreinir sjötta áratug tuttugustu aldar sem tímabil nútíma samfélagsábyrgðar (Carroll, 1999). Hugtakið sjálft, p.e. samfélagsábyrgð fyrirtækja (e. corporate social responsibility) var fyrst sett fram af Howard Bowen árið 1953 í bók sem bar yfirskriftina „Social Responsibilities of the Businessman“. Skilgreining Bowen er talin grunnskilgreining sem stuðst hefur verið við í fræðum um samfélagsábyrgð fyrirtækja, en síðan hefur smátt og smátt verið byggt ofan á hana. Að mati Bowen felst skylda stjórnenda í pví:

...að fylgja eftir stefnu, taka ákvardanir og framkvæma hluti sem eru eftirsóknarverðir fyrir samfélagið ( Carroll, 1999).

Pegar litið er til próunar og skilnings á hugtakinu kemur í ljós að sagan er löng og skilningurinn á hugtakinu hefur próast í áranna rás. Í raun má segja að samfélagsábyrgð fyrirtækja sé pverfaglegt viðfangsefni og hafa fræðimenn ólíka sýn á hvað felst í raun í hugtakinu. Carroll (1999) dregur fram prjá pætti p.e.: a) ábyrgð gagnvart hluthöfum, b) ábyrgð gangvart öðrum haghöfum og c) ábyrgð gagnvart samfélaginu.

Samfélagsábyrgð fyrirtækja er pannig hugtak sem ætlað er að ná utan um siðferðislega, félagslega, umhverfislega, efnahagslega og lagalega ábyrgð fyrirtækja. Pví er einnig haldið fram að fyrirtæki sinni samfélagslegri ábyrgð sjálfviljug og gangi lengra en lög og reglur gera kröfur um (Blowfield og Murray, 2014). Áherslur á svið samfélagsábyrgðar eru einnig mismunandi eftir löndum og heimsálfum, en pað ræðst meðal annars af lagaumhverfi og samfélagsaðstæðum sem móta rekstrarumhverfi fyrirtækjanna (Blowfield og Murray, 2014). Samfélagsábyrgð fyrirtækja í Bandaríkjunum hefur verið skilgreind sem opinská (e. explicit), 
p.e. að fyrirtæki fari ekki leynt með áherslur sínar, á meðan hún er sögð hulin (e. implicit) í Evrópu í peirri merkingu að fyrirtækin eru ekki endilega að segja frá áherslum sínum og aðgerðum (Matten og Moon, 2008). Evrópusambandið (ESB) stendur engu að síður framarlega á sviði samfélagsábyrgðar, en framkvæmdastjórn sambandsins gaf t.d. út svokallaða grænbók (e. Green paper) árið 2001 en par var settur fram rammi um málefni samfélagsábyrgðar (European Commission, 2001). Samfélagsábyrgð hefur síðan átt sinn stað í stefnumótun ESB á sviði vinnu- og félagsmála, umhverfismála, neytendamála, utanríkismála og stefnumótunar í málefnum opinberra innkaupa og fyrirtækjareksturs. Einnig eru ýmis verkefni í gangi á vegum sambandsins sem miða að sjálfbærri próun, auknum hagvexti og atvinnusköpun ásamt viðskiptasiðferði (Dagný Arnarsdóttir, 2011). Í endurskoðaðri stefnu Evrópusambandsins um samfélagsábyrgð fyrirtækja fyrir árin 2011-2014 hvetur sambandið fyrirtæki til að finna farveg til að sampætta félagsleg og umhverfisleg málefni, mannréttindi og neytendavelferð við meginstefnu og dagleg störf í samstarfi við haghafa fyrirtækjanna (European Commission, 2011). Nánari skilgreiningu á samfélagsábyrgð má finna á vefsíðu Evrópusambandsins:

Samfélagsábyrgð vísar til pess að fyrirtæki taki ábyrgðááhrifum sinum ásamfélagið.
Vísbendingar eru um að samfélagsábyrgð hafi i auknum mæli áhrif á
samkeppnishæfni fyrirtækja. Samfélagsábyrgð getur skilað ávinningi i
áhættustjórnun, dregið úr kostnaði, haft áhrif á aðgengi að fjármagni, samband við
viðskiptavini, mannauðsmál og nýsköpun (European Commission, e.d.).

Pessi skilgreining Evrópusambandsins er studd viðmiðum og stöðlum ýmissa stofnana og samtaka sem fjalla um efnið s.s. Alpjóðlegu staðlasamtakanna (ISO) sem hafa próað staðal um samfélagsábyrgð (ISO 26000) með aðkomu fjölda hagsmunaðila víða um heim. Staðlinum er ætlað að veita leiðbeiningu um meginreglur samfélagsábyrgðar, viðurkenningu og virkjun hagsmunaðila en einnig að benda á leiðir til pess að innleiða samfélagsábyrgð. Staðallinn er hins vegar ekki ætlaður til vottunar eins og á við um ýmsa aðra staðla, heldur er hér um leiðbeiningarstaðal að ræða (Staðlaráð Íslands, 2013). Samkvæmt staðlinum felst samfélagsábyrgð í ...

...vilja fyrirtækis til að innleiða samfélags- og umhverfislega hugsun i ákvörðunum
sínum og að pað taki afleiðingum af áhrifum sem ákvarðanir pess og starfsemi hafa
á samfélagið og umhverfið. Dað felur í sér bæði gagnsæja og siðferðilega háttsemi sem
stuðlar að sjálfbærri próun, er i samræmi við gildandi lög og reglur og fylgir
alpjóðlega viðtekinni háttsemi. Dað felur einnig i sér að samfélagsleg ábyrgð sé
innleidd i fyrirtækinu öllu, sé viðhöfð i öllum samskiptum pess og taki tillit til
hagsmuna hagsmunaaðila (Staðlaráð Íslands, 2013, bls. 30).

Pannig má segja að dregið sé fram pað sjónarmið að samfélagsábyrgð sé ekki verkefni á hliðarlínunni, heldur að hún sé heildstæð, tengd kjarnastarfsemi viðkomandi fyrirtækis, taki mið af breiðum hópi hagsmunaaðila og ekki sé eingöngu horft til skammtímasjónarmiða heldur að pað sé jafnvægi á milli skammtíma- og langtímasjónarmiða í rekstri fyrirtækja (Chandler og Werther, 2014).

Fyrirtæki geta stigið ýmis skref til að formgera samfélagsábyrgð sína, meðal annars með pví að (i) setja fram skriflega stefnu, (ii) gera ljóst hver eða hverjir beri ábyrgð á peim málum í fyrirtækinu, (iii) skilgreina verkefni og ferla sem snerta samfélagsábyrgð og (iv) gera grein fyrir aðgerðum og árangri varðandi samfélagsábyrgð með skýrslum og á annan hátt. Lítil 
fyrirtæki geta tekið samfélagsábyrgð sína mjög alvarlega án pess að formgera ábyrgðina um of. Í peim tilvikum er samfélagsábyrgðin oft hluti af grunnhugmyndum um reksturinn, t.d. hluti af pví sem stofnendur standa fyrir (Killian, 2012; Russo og Tencati, 2009).

Á Íslandi hafa verið starfræktar miðstöðvar um samfélagsábyrgð allt frá árinu 2008, fyrst Epikos og síðan Festa, miðstöð um samfélagsábyrgð, en Festa var stofnuð árið 2011. Aðild að Festu er ætlað að auðvelda fyrirtækjum að vinna með samfélagsábyrgð í eigin rekstri (Rio Tinto Alcan, 2008). Einnig eru nú starfandi ráđgjafarfyrirtæki eins og t.d. Alta og Roadmap sem sinna ráðgjöf varðandi samfélagsábyrgð. Festa er sjálfstæð stofnun sem hefur pað að markmiði að hvetja til aukinnar umræðu og rannsókna um samfélagsábyrgð á Íslandi en jafnframt að bjóða upp á fræðslu og upplýsingagjöf til fyrirtækja (Festa, e.d. a). Á heimasíðu Festu má finna skilning miðstöðvarinnar á samfélagsábyrgð. Par segir:

Í sinni einföldustu mynd felst samfélagsleg ábyrgð fyrirtækja og stofnana i pví að pau axli ábyrgð á peim áhrifum sem pau hafa á fólk og umhverfið. Samfélagsábyrgð fyrirtækja miðar að jafnvægi par sem úr verður gagnkvæmur ávinningur fyrir samfélagið og fyrirtækin sjálf. Ábyrg félög eru pau sem með markvissum hætti skipuleggja starfsemi sína pannig að pau skaði ekki samfélagið og umhverfið heldur hafi jákvæð áhrif á próun samfélagsins (Festa, e.d. a).

Festa bendir á að samfélagsábyrgð fyrirtækja sé tæki fyrir ábyrg fyrirtæki og stofnanir til að koma sér upp ferlum og skipulagi til að koma í veg fyrir að pau valdi skaða með starfsemi sinni (Festa, e.d. b). Í samfélagsábyrgð felst pannig ákveðið viðhorf sem endurspeglast í pví að hægt sé að hafa jákvæð og góð áhrif á samfélagið og umhverfið um leið og árangri í viðskiptum er náð.

Pegar horft er til eðlis samfélagsábyrgðar fyrirtækja er ljóst að hún tekur á sig margar ólíkar myndir sem meðal annars eru háðar eðli starfseminnar, stærð fyrirtækisins, hvar fyrirtækið starfar og tíma. Pannig eru umhverfismál mikilvægur páttur í samfélagsábyrgð fyrirtækja sem eru stórtæk í nýtingu náttúruauðlinda, mannréttindi hjá fyrirtækjum sem eru með starfsemi í próunarlöndum og viðskiptasiðferði hjá fyrirtækjum með starfsemi í löndum par sem mútur eru landlægar. Stærð fyrirtækja hefur einnig mikil áhrif á pað hvernig fyrirtæki nálgast samfélagsábyrgð og í töflu 1 er dreginn fram áherslumunur á samfélagsábyrgð hjá litlum og meðalstórum fyrirtækjum annars vegar (10-250 starfsmenn) og stórum fyrirtækjum hins vegar, eins og Vázquez-Carrasco og López-Pérez (2013) og Jamali og fleiri (2009) greina petta. 
Tafla 1. Áherslumunur á samfélagsábyrgð lítilla og meðalstórra fyrirtækja samanborið við samfélagsábyrgð hjá stórum fyrirtækjum Heimild: Byggt á Vázquez-Carrasco og López-Pérez, 2013 og Jamali og fleiri, 2009.

\begin{tabular}{|l|l|}
\hline $\begin{array}{l}\text { Lítil og meðalstór fyrirtæki (10-250 } \\
\text { starfsmenn) }\end{array}$ & Stór fyrirtæki (fleiri en 250 starfsmenn) \\
\hline Mannúðarmál. & $\begin{array}{l}\text { Efnahagslegt sjónarhorn, stefnumiðuð } \\
\text { nálgun. }\end{array}$ \\
\hline $\begin{array}{l}\text { Aðstæðubundið (áhersla á afmarkaða } \\
\text { rekstarpætti). }\end{array}$ & $\begin{array}{l}\text { Heildstæð nálgun (áhersla á } \\
\text { heildarstarfsemi fyrirtækisins). }\end{array}$ \\
\hline $\begin{array}{l}\text { Meiri nálægð við hagsmunaaðila. Áhersla á } \\
\text { nærsamfélagið. }\end{array}$ & Meiri fjarlægð frá hagsmunaaðilum. \\
\hline $\begin{array}{l}\text { Sterkur innblástur, veik sampætting, } \\
\text { nýsköpun í meðlagi. }\end{array}$ & $\begin{array}{l}\text { Veikur innblástur, öflug sampætting, lítil } \\
\text { nýsköpun. }\end{array}$ \\
\hline Siðræn sjónarmið, gildismat eigenda. & $\begin{array}{l}\text { Hagkvæmnisjónarmið, efnahagsleg } \\
\text { markmið. }\end{array}$ \\
\hline Ókerfisbundið, ómótað og lítt formgert. & Skipulagt, formgert, mælanlegt. \\
\hline
\end{tabular}

Samkvæmt skilgreiningu framkvæmdastjórnar Evrópusambandsins pá teljast fyrirtæki með færri en 50 starfsmenn smáfyrirtæki, fyrirtæki með starfsmannafjölda á bilinu 51-249 teljast meðalstór, en fyrirtæki með 250 starfsmenn eða fleiri teljast stór (European Commission, 2005). Eins og sjá má í töflu 2 myndu íslensku skaðatryggingafélögin teljast meðalstór samkvæmt skilgreiningu peirra Vázquez-Carrasco og López-Pérez og Evrópusambandsins. Vegna smæðar fyrirtækja á Íslandi er vert að hafa í huga að íslensku skaðatryggingafélögin teljast til stórra fyrirtækja hér á landi, en myndu í alpjóðlegum samanburði teljast smá. Par sem pau eru stór fyrirtæki í smáu samfélagi pá er ekki ólíklegt að litið sé á pau sem fyrirmynd og gert ráð fyrir að pau gangi á undan með góðu fordæmi á sviði samfélagsábyrgðar, sem og á ýmsum öðrum sviðum rekstrarins.

Tafla 2. Fjöldi starfsmanna hjá íslensku skaðatryggingafélögunum

\begin{tabular}{|l|l|}
\hline Vátryggingafélag & Fjöldi starfsmanna \\
\hline Sjóvá & 180 \\
\hline TM & $127(+25$ umboðsmenn $)$ \\
\hline VÍS & 201 \\
\hline Vörður & 65 \\
\hline
\end{tabular}

Með aukinni alpjóðavæðingu hefur krafan um að fyrirtæki taki pátt í að bæta pað samfélag sem pau starfa í orðið meira áberandi eins og nefnt hefur verið hér að framan. Erlendar rannsóknir hafa gefið vísbendingar um að samfélagsábyrgð geti haft áhrif á kauphegðun neytenda sem segjast vera tilbúnir til pess að breyta kauphegðun sinni og beina viðskiptum sínum frekar til fyrirtækja sem eru samfélagslega ábyrg (Kotler og Lee, 2005). Aukinn prýstingur hefur einnig myndast frá fjárfestum, opinberum aðilum og starfsmönnum sem gera pá kröfu á fyrirtækin að pau starfi á samfélagslega ábyrgan hátt (Fuentes-García o.fl., 2008 og Renneboog o.fl., 2008). Pessi prýstingur endurspeglast t.d. í alpjóðasamningum á sviði umhverfismála, löggjöf og prýstingi frá ýmsum hagsmunaöflum sem kalla eftir nýjum gildum, nýjum viðskiptaháttum og nýrri framtíðarsýn með aukna ábyrgð að leiðarljósi (Hoffman, 
2000). Krafa um að árangur samfélagsábyrgðar verði mældur og niðurstöður birtar hagsmunaaðilum eykst einnig (Rose, 2013; Council of the European Union, 2014), sérstaklega meðal stærri fyrirtækja.

Bæði sjálfstæðar stofnanir og alpjóðastofnanir hafa brugðist við nýjum áskorunum sem fyrirtæki eiga pátt í að skapa, en par má nefna hnattvæðingu aðfangakeðja, fátækt, hnignun vistkerfa og loftslagsbreytingar, með próun á viðmiðum og stöðlum sem fyrirtæki geta fylgt til pess að bæta reksturinn (Blowfield og Murray, 2014). Alpjóðlegu staðlasamtökin eru par gott dæmi með ISO 26000 staðalinn, sem nefndur var hér að framan. Fleiri dæmi má nefna, t.d. UN Global Compact sáttmála Sameinuðu pjóðanna um samfélagsábyrgð. Sáttmálanum er ætlað að stuðla að pví að fyrirtæki axli samfélagsábyrgð í verki með viðmiðum sem pau geta nýtt sér við innleiðingu samfélagsábyrgðar. Fyrirtæki gerast sjálfviljug aðilar að Global Compact, en pá skuldbinda pau sig til pess að uppfylla tíu meginreglur sem lúta að mannréttindum, vinnurétti, umhverfismálum og baráttu gegn spillingu. Til pess að halda aðild sinni að sáttmálanum eru fyrirtæki skyldug til pess að skila árlegri skýrslu par sem fram kemur hvernig peim miðar við að fara eftir pessum reglum og hvaða áætlanir eru í gangi par að lútandi (United Nations Global Compact, e.d.).

Global Reporting Initiative (GRI) eru sjálfstæð samtök sem hafa próað alpjóðleg viðmið um gerð sjálfbærniskýrslna, en áherslan er á gagnsæi og áreiðanleika upplýsinga sem fyrirtæki setja fram í skýrslum sínum. Meginviðmið GRI-skýrslna snúa að umhverfi, mannréttindum, vinnuafli, samfélaginu og ábyrgum viðskiptum og efnahag. Fyrirtæki sem ákveða að innleiða pessi viðmið við skýrslugerð ráða sjálf hversu stóran hluta af peim pau innleiða (Global Reporting Initiative, e.d.). Ásthildur Hjaltadóttir (2012), aðstoðarframkvæmdastjóri hjá The Global Reporting Initiative, segir pað algengt að fyrirtæki tryggi gagnsæi og segi opinberlega frá stefnu sinni og aðgerðum á sviði samfélagsábyrgðar með pví að birta upplýsingar um áhrif sín á samfélagið og umhverfið, t.d. í formi GRI-skýrslna. Hún segir jafnframt að GRI-viðmiðin séu vel pekkt í Skandinavíu, pó ekki sé sömu sögu að segja frá Íslandi. Ásthildur telur líklegt að hér á landi eigi krafan um aukið upplýsingaflæði um samfélagsábyrgð eftir að aukast, ekki síst í ljósi pess að Evrópupingið hefur sampykkt tilskipun sem tekur gildi árið 2017, en hún skyldar stærri fyrirtæki með 500 starfsmenn eða fleiri til að birta upplýsingar um samfélagsábyrgð sína (Council of the European Union, 2014). Pá hefur slík löggjöf pegar verið innleidd í Danmörku svo að dæmi sé tekið (Zandvliet, 2011).

\section{Hlutverk skaðatryggingafélaga}

Meginhlutverk skaðatryggingafélaga er að koma í veg fyrir tjón og vernda líf og eignir. Hlutverk peirra er pannig ekki einungis fjárhagslegs eðlis heldur hefur pað víða samfélagslega skírskotun. Skaðatryggingafélögin dreifa áhættu sem pau tryggja með pví að kaupa sér vernd hjá endurtryggingafélögum. Skaðatryggingafélög eru einnig stórir fjárfestar á markaði og stórir kaupendur ýmissar pjónustu, sér í lagi á sviði tjóna, ásamt pví að vera vinnuveitendur. Vegna áhrifa loftslagsbreytinga á rekstrarumhverfi vátryggingafélaga pá hafa norræn fjármála- og vátryggingasamtök gefið út sérstaka yfirlýsingu par að lútandi. Par er lögð sérstök áhersla á kjarnastarfsemi vátryggingafélaga, p.e. vörur og pjónustu, forvarnarmál og meðhöndlun tjóna, fjárfestingar, auk eigin starfsemi og eftirfylgni (Bosse og fleiri, 2009). Samtök fjármálafyrirtækja (SFF), sem eru heildarsamtök fjármálafyrirtækja á Íslandi, voru ekki aðili að umræddri loftslagsyfirlýsingu systursamtakanna á Norðurlöndum. 
Samkvæmt heimasíðu SFF eru aðildarfélögin viðskiptabankar, fjárfestingarbankar, sparisjóðir, vátryggingafélög, verðbréfafyrirtæki, eignaleigur og kortafélög (Samtök fjármálafyrirtækja, e.d. a). Á heimasíðu SFF segir:

Fjármálastarfsemi er ein af grunnstoðum samfélagsins og poí bera fjármálafyrirtæki mikla samfélagslega ábyrgð (Samtök fjármálafyrirtækja, e.d.b).

Samtökin leggja til viðmið sem mælst er til að lögð séu til grundvallar í siða- og verklagsreglum fjármálafyrirtækja. Lögð er til virðing fyrir lögum, viðskiptavinum, starfsfólki og ólíkum hagsmunum haghafa. Einnig er lögð áhersla á virðingu og trúnað, virðingu einkalífs og samfélagsleg áhrif ákvarðana. Samtökin leggja pannig til að:

\section{Fjármálafyrirtæki leitast við að gera starfsmenn sína meðvitaða um samfélagsleg áhrif peirra fjárhagslegu ákvarðana sem peir taka í starfi. Starfsmenn taka tillit til samfélagslegra sjónarmiða eftir poí sem kostur er pegar taka parf erfiðar ákvarðanir sem geta varðað lífsviðurværi fólks (Samtök fjármálafyrirtækja, e.d.b).}

Að öðru leyti er ekki fjallað um samfélagsábyrgð á heimasíðu Samtaka fjármálafyrirtækja. Pess utan bendir Rose (2013) á mikilvægi pess að viðskiptavinir skaðatryggingafélaga geti treyst pví pegar peir verða fyrir áföllum að aðrir hagsmunir en eingöngu fjárhagslegir stjórni aðgerðum skaðatryggingafélaga. Til pess að tileinka sér slíka starfshætti leggur Rose til eftirfarandi:

1. Borga „réttar“ bætur, p.e. pannig að bótapeginn fái sanngjarnar bætur fyrir tjón sitt, ekki svo lágar að honum finnst hann svikinn og heldur ekki svo háar að pað verði til pess að hækka iðgjöld. Til pess að svo megi verða parf vátryggingafélagið að búa yfir hæfu starfsfólki, tækni og tækjum.

2. Peningar bæta ekki tjón að fullu og pví ættu tryggingafélög að beita sér á sviði forvarna hvar sem pau hafa tækifæri til.

3. Taka forystu hvað varðar loftslagsbreytingar. Bent er á að fjármálastofnanir sem gerast aðilar að United Nations Environment Programme Finance Initiative (UNEP Finance Initiative) skrifi undir sáttmála á sviði umhverfismála. Nú pegar hafa yfir 200 fyrirtæki í fjármálastarfsemi í heiminum skrifað undir sáttmálann, par sem pau undirgangast að vera í forystu um að próa með sér góða umhverfislega hegðun (UNEP Finance Initiative, e.d.).

4. Taka pátt í góðgerðamálum á stefnumiðaðan hátt, helst pannig að pau verkefni sem studd eru tengist kjarnastarfsemi, t.d. dragi úr slysum og eignatjónum.

5. Virða mannréttindi.

6. Viðhafa samfélagslega ábyrga fjárfestingastefnu.

\section{Rannsóknaraðferð}

Eigindleg aðferðarfræði (e. qualitative research method(s)) leggur áherslu á að einstaklingurinn sé virkur túlkandi, en pannig beinast eigindlegar rannsóknaraðferðir að pví að skilja hvernig einstaklingar skynja umhverfi sitt og aðstæður. Eigindlegar rannsóknaraðferðir eru ólíkar peim megindlegu að pví leyti að pær eru sveigjanlegri og rannsóknarspurningar eru að mótast á meðan á rannsókninni stendur. Í eigindlegri 
aðferðarfræði er ekki stefnt að pví að fá víðtæka, tölfræðilega yfirsýn eins og með megindlegum rannsóknaraðferðum heldur reynt að lýsa aðstæðum, atburðum og viðhorfum eins nákvæmlega og kostur er (Taylor og Bogdan 1998; Rasmussen, 2006). Kenningar eða tilgátur eru oft unnar upp úr gögnunum og próast pegar líður á rannsóknina, enda mótast áherslur á meðan á rannsókn stendur (Taylor og Bogdan 1998; Strauss og Corbin, 1998).

Beitt var eigindlegri aðferðarfræði við pessa rannsókn og tekin viðtöl við forsvarsmenn skaðatryggingafélaganna fjögurra vorið 2014. Tekin voru alls fimm viðtöl í fjórum félögum. Áður en viðtölin fóru fram var sendur tölvupóstur til forstjóra félaganna par sem óskað var eftir pátttöku peirra í rannsókninni, en einnig var óskað eftir ábendingu um aðila, einn eða fleiri, sem myndu henta vel til viðtals í ljósi sérpekkingar viðkomandi á málaflokknum. Öll félögin sem leitað var til sampykktu pátttöku. Að loknu hverju viðtali var viðmælandi spurður hvort hann vildi benda á annan viðmælanda sem bætt gæti við upplýsingum um samfélagslegar áherslur viðkomandi félags. Раð var gert í einu vátryggingafélaganna, en ekki í hinum. Pví fóru fram tvö viðtöl í einu félaganna, en eitt í hinum premur. Viðtölin tóku frá 22 til 48 mínútur.

Skoðun á aðgengilegum gögnum á vefsíðum skaðatryggingafélaganna var mikilvægt skref í framkvæmd rannsóknarinnar. Vefsíður félaganna voru skoðaðar m.t.t. málefna sem vörðuðu samfélagsábyrgð. Út frá upplýsingum sem par komu fram var próaður spurningarammi (sjá fylgiskjal 1) sem hafður var til hliðsjónar í viðtölunum en viðmælenda var pó gefið svigrúm til pess að tjá sig út fyrir efnið að vild. Viðtölin voru pannig hálfopin. Mátt hefði nota atriðin sem Rose (2013) tilgreinir hér að framan sem hluta af viðtalsrammanum. Рað var ekki gert par sem pað hefði stýrt umræðunni um of, í stað pess að láta viðmælendur sjálfa, sem og gögn af vefsíðum, segja til um pað hvar megináherslur íslenskra skaðatryggingafélaga á sviði samfélagsábyrgðar liggja. Viðmið Rose var síðan notað til hliðsjónar í umræðu til að skoða hvort áherslur hérlendra vátrygginga séu í takt við pær áherslur sem ætla mætti að kæmu fram í viðtölunum.

Viðtölin voru öll tekin upp með leyfi viðmælanda og síðan afrituð frá orðið til orðs í Word. Í framhaldinu var leitað eftir pemum, bæði með opinni og markvissri kóðun á upplýsingum sem fram komu í viðtölunum (Creswell, 2007). Opin kóðun felur í sér að gögnin eru lesin yfir línu fyrir línu til að draga fram áhugaverða flokka, hugtök og pemu, en markviss kóðun miðar að pví að leita að tilteknum atriðum eða pemum í gögnunum eins og t.d. stefnu eða hvötum. Einnig er notast við beinar tilvitnanir, p.e. vitnað er beint í viðmælendur. Upplýsingar sem fram komu á vefsíðunum voru einnig notaðar á síðari stigum til staðfestingar á pví sem fram kom í viðtölunum (e. triangulation) (Creswell, 2007).

\section{$5 \quad$ Niðurstöður}

Hér á eftir er fjallað um helstu pemun sem fram komu í viðtölum við forsvarsmenn íslensku skaðatryggingafélaganna.

\subsection{Stefna}

Tvö félaganna, Sjóvá og VÍS, hafa sett stefnu um samfélagslega ábyrgð. VÍS setti sér stefnu um samfélagsábyrgð árið 2013 (VÍS, e.d. c). Sjóvá setti fram stefnu um samfélagslega ábyrgð í mars 2012 um leið og settar voru siðareglur fyrir félagið (Sjóvá, 2012). Sjóvá hefur sett „forvarnarmiðaða stefnu“ sem á pó reyndar eftir að endurnýja samkvæmt viðmælanda sem ekki á von á að hún breytist mikið vegna pess að: 
við erum með svipaðan fókus, hlutverk okkar er að tryggja verðmæti i lífi fólks með áherslu á forvarnir og við erum svolítið að horfa á okkar kjarnastarfsemi (Viðmælandi frá Sjóvá).

VÍS hefur stigið skrefinu lengra og hefur sett stefnu sem byggir á sex meginstoðum en pær eru forvarnir, samstarfsaðilar, stjórnarhættir, mannauður, umhverfi og samfélag (VÍS, e.d.a). Bæði TM og Vörður hafa tekið, eða eru u.p.b. að taka, fyrstu skrefin í átt að pví að móta stefnu um samfélagsábyrgð, eða skoða hvort pað purfi að setja sér stefnu á pessu sviði eins og sjá má á svörum viðmælenda:

.....taka petta út frá samfélagsábyrgðinni. Рað var ákveðið i stefnumótunarvinnu í haust að gera pað og svo í framhaldi að fara inní Festu. Рað sem við höfum verið að gera er að reyna að læra af peim sem eru komin lengst og pað gerum við i gegnum Festu (Viðmælandi frá Verði).

... pað er búið að setja saman vinnuhóp sem á að skila tillögum til stjórnar í september (Viðmælandi 1 frá TM).

... en við höfum hins vegar velt pví fyrir okkur hvort við purfum raunverulega sérstaka stefnu í pessum málaflokki poí að i raun snýst starfsemi tryggingafélaga um samfélagslega ábyrgð (Viðmælandi 2 frá TM).

\subsection{Hvatar}

Pegar spurt er um helstu hvata félaganna fyrir pví að pau hafi sett, eða setji sér, stefnu um samfélagsábyrgð og innleiði hana pá eru félögin öll sammála um að hvatinn komi helst innan frá, p.e. frá félögunum sjálfum. Pó má einnig merkja í svörum ytri prýsting, sem meðal annars felst í kröfu um gagnsæja og góða stjórnarhætti en sá prýstingur byggir til að mynda á leiðbeiningum sem gefnar hafa verið út á vegum Viðskiptaráðs Íslands, Samtaka atvinnulífsins og NASDAQ OMX Iceland (Lára Jóhannsdóttir, 20. ágúst 2014). Par sem öll félögin nema Vörður eru skráð félög á markaði er eðlilegt að slík krafa sé gerð til peirra.

... okkur finnst mjög mikilvægt að við séum að vinna á samfélagslega ábyrgan hátt, og að pað hríslist um allt fyrirtækið (Viðmælandi frá Verði).

Ég held að prýstingurinn komi bara mest innan frá, við viljum uppfylla kröfur um gagnsæja og góða stjórnarhætti (Viðmælandi frá Sjóvá).

... við erum með stjórn sem að er mjög meðvituð á pessu sviði og stjórnarmennirnir hafa bæði setið i félögum og reka félög sem hafa sett sér skýr markmið eða markað sér skýra stefnu á pessu sviði. Deir vildu fá pessa umræðu i gang hér, hún var hinsvegar löngu byrjuð, pað i rauninni var ákvörðun stjórnarinnar að fara pá leið að marka stefnu og sú vinna er bara í gangi (Viðmælandi 2 frá TM).

Viðmælendur eru allir sammála um að viðskiptavinir séu ekki prýstihópur í pessu tilliti enn sem komið er, jafnvel pó að peir kunni vel að meta að unnið sé markvisst í málaflokknum. 
....nei, ég get ekki sagt að ég finni pað [prýsting frá viðskiptavinum] í daglegum störfum. Ég held að pað sé frekar pannig að við í pessum málum, eins og svo mörgu öðru, erum kannski 10-15 árum á eftir Skandinavíu og ég heyri frá vinum mínum sem búa i Skandinavíu að petta sé eitthvað sem fólk pæli í af einhverri alvöru par og pess vegna býst ég við að pað muni koma hérna (Viðmælandi 1 frá TM).

... ég held að peir [viðskiptavinirnir] kunni að meta margt af pví sem er [gert] og finnist pað vera góðs viti að við séum að vinna i forvörnum til dæmis og pað fari vel að við skilgreinum pað sem okkar hlutverk (Viðmælandi frá VÍS).

\section{3 Áherslupættir}

Pegar skoðaðir eru helstu áherslupættir skaðatryggingafélaganna sem setja má undir hatt samfélagsábyrgðar kemur í ljós að forvarnir eru par fyrirferðamestar í ljósi eðli starfseminnar, bæði hjá peim félögum sem hafa sett sér formlega stefnu í málaflokknum en einnig peim sem ekki hafa gert slíkt. Pannig má draga úr slysum og tjónum og í framhaldinu jafnvel lækka iðgjöld. Félögin leggja öll nokkra áherslu á að styðja við ýmiss konar íprótta- og forvarnarstarf. Sem dæmi má par nefna Kvennahlaupið sem Sjóvá hefur stutt frá upphafi, en einnig stuðning við kvennaknattspyrnu, barnabílstóla og margt fleira.

...við tengjum petta inní hlutverk okkar. Dað má segja að forvarnir hafi skipað stóran sess í hlutverki okkar og inní samfélagslegu ábyrgðina (Viðmælandi frá VÍS).

Öll hafa félögin lengi lagt áherslu á styrkveitingar og eru slíkar áherslur áberandi á heimasíðum peirra. Sumar styrkveitingar tengjast forvörnum en aðrar ekki.

Öll félögin fjögur gefa kynjajafnrétti góðan gaum, bæði í viðtölunum og á heimasíðum sínum. Prjú af félögunum fjórum hafa fengið jafnlaunavottun. Sjóvá og Vörður fengu vottun frá VR árið 2014 (VR, 2014, Vörður, 2014), en áður hafði VÍS fengið Gullmerkið árið 2011, en pað er jafnlaunavottun PwC (VÍS, 2012). Vörður hefur einnig hlotið Gullmerki PwC (Viðskiptablaðið, 2014). Helstu áherslupættir félaganna snúa að pví að kynin eigi að hafa sömu laun fyrir sömu vinnu og að launamunur eigi einungis að endurspegla menntun, ábyrgð, vinnuframlag og getu en ekki kynferði. Annars konar jafnrétti er ekki gefinn gaumur, t.d. jafnrétti fatlaðra eða fólks af erlendum uppruna.

Umhverfismál eru áherslupáttur hjá félögunum fjórum, en flest pað sem pau hafa gert má fella undir раð аð draga úr úrgangi og sóun, t.d. með flokkun úrgangs og minni pappírsnotkun. Félögin hafa öll hafið flokkun á raftækjaúrgangi og hafa gert samning við Græna framtíð um endurvinnslu á raftækjum, Sjóvá og TM árið 2009, VÍS 2010 og Vörður 2014. Í pví samhengi má nefna að hér eru pau í sjálfu sér ekki að ganga lengra en lög og reglur gera ráð fyrir, sé horft til reglugerðar nr. 1104/2008 um raf- og rafeindatækjaúrgang. Í reglugerðinni er tilgreind ábyrgð framleiðenda og innflytjenda á að fjármagna og tryggja meðhöndlun rafog rafeindatækjaúrgangs. Pó svo að vátryggingafélög séu hvorki framleiðendur né innflytjendur pá fjármagna pau kaup á umtalsverðu magni slíks búnaðar með tjónagreiðslum.

Einnig má nefna að vátryggingafélög hafa dregið mjög úr prentun með fækkun prentara og aðgangsstýringu á prentun. Pau hvetja einnig til pappírslausra viðskipta og árið 2012 voru tjónstilkynningar orðnar pappírslausar hjá TM. Pessar áherslur hafa ekki síður fjárhagslegan ávinning fyrir félögin en umhverfislegan.

Tvö félaganna bjóða starfsmönnum sínum uppá samgöngusamning par sem starfsmönnum er boðinn styrkur ef peir ferðast til og frá vinnu á umhverfisvænan hátt. Hvað 
varðar viðskiptavini pá býður TM afslátt af iðgjöldum fyrir bifreiðar sem ganga fyrir umhverfisvænum orkugjöfum.

Öll félögin fjögur hafa gerst aðilar að Festu, miðstöð um samfélagsábyrgð, p.e. Vörður árið 2013 og VÍS, Sjóvá og TM árið 2014. Pá hefur VÍS, eitt skaðatryggingafélaganna, skrifað undir jafnréttissáttmála UN Women, en sáttmálinn er samstarfsverkefni UN Women og UN Global Compact (UN Women á Íslandi, e.d.). Pví má einnig bæta við að ekkert félaganna gefur út skýrslur sem taka mið af GRI-viðmiðunum sem nefnd voru að framan. Viðmælendur telja að skýrslugjöf á pessu sviði sé yfirgripsmikil og taki tíma frá daglegum störfum.

... við erum ekki farin í skýrsluskil og pað allt, við erum í rauninni bara með (jafnréttis?) undirritað að huga að jafnréttismálum og pess vegna eru jafnréttismálin svona stór páttur í mannauðspartinum hjá okkur (Viðmælandi frá VÍS).

Hin félögin hafa skoðað UN Global Compact sáttmálann en eru ekki viss um að skrifa undir hann af eftirfarandi ástæðum:

... ég sé alveg fyrir mér að við munum fara aðeins aðra leið. Dað á bara eftir að koma í ljós og auðvitað er mismikið sem á við í pessum Global Compact, pað er bara eins og pað gengur en pað á bara eftir að koma í ljós (Viðmælandi 1 frá TM).

...pá held ég að svona skýrslugerð geti verið mjög flókin, hún getur náttúrlega verið einföld pað fer bara eftir poí hverskonar leið maður velur í henni. Mér finnst líklegt að við byrjum smátt og kannski vinnum okkur áfram. Ég sé ekki að pað verði bara jæja nú er pað Global Compact og GRI, ég sé pað ekki gerast alveg í nánustu framtíð (Viðmælandi frá Sjóvá).

\section{4 Ávinningur af innleiðingu samfélagsábyrgðar}

Viðmælendur virtust sammála um að samfélagsábyrgð geti skipt máli hvað varðar samkeppnishæfni. Flestir viðmælendur voru einnig sammála um að mikilvægi samfélagsábyrgðar myndi aukast á næstu árum, bæði fyrir viðskiptavini og fjárfesta og að ávinningurinn gæti pá orðið fjárhagslegur fyrir fyrirtæki sem standa sig vel á pessu sviði, t.d. pannig að pau hafi öðlist betri ímynd í hugum fjárfesta.

....kannski til lengri tíma litið, ég held að petta geti hjálpað okkur gagnvart fjárfestum, ég hugsa að ef við myndum ekki gera petta [taka skref í átt að samfélagsábyrgð] á næstu premur árum að pá gæti pað haft mögulega áhrif á ímynd okkar ganguart fjárfestum (Viðmælandi 2 frá TM).

\subsection{Hindranir við innleiðingu}

Pegar spurt var um helstu hindranir við innleiðingu á stefnu um samfélagsábyrgð kom í ljós аð pað er helst tímaskortur, forgangsröðun verkefna, skilningur/stuðningur starfsmanna og stærð félaganna sem háir peim við innleiðingu samfélagsábyrgðar.

... sko, hindranir pað er alltaf petta tímaleysi... pað er klárt að bæði gæðamálin, samfélagsábyrgðin og allt petta, petta er ekki pað sem snýr að daglegum verkefnum og menn purfa alltaf fyrst að láta pjónustuna ganga fyrir. Pað verður svolítið til pess að pessu er alltaf svolítið ýtt til hliðar... (Viðmælandi frá Verði). 


\begin{abstract}
Ég held einhvern veginn að okkur verði að lánast að finna svona kjarnann í pessu og stundum verðum við bara að fara, að taka einhverjar svona skemmri leiðir annars held ég að petta muni ekki lifa. Ef petta verður alltof dýrt og alltof mikið effort, ef maður getur orðað pað pannig, að vinna að pessum hlutum pá held ég að petta fái ekki framgang i fyrirtækjum, petta bara verður alltaf undir, af pví að pað er svo margt annað sem kannski er meira aðkallandi, allavega eins og ég sé petta (Viðmælandi frá VÍS).
\end{abstract}

Stuðningur og skilningur starfsmanna skiptir miklu máli pví án hans gerist lítið eftir pví sem fram kemur í svörum viðmælenda. Petta getur reynst erfitt pví ómögulegt er að póknast öllum og fólk hefur sínar skoðanir á pví hversu langt á að ganga, hversu mikið á að gera.

...menn eiga eflaust eftir að takast á um pað hversu langt eigi að ganga í pessu.... Dá auðvitað gætum við lent á einhverjum veggjum og i einhverjum rökræðum um hvað sé nákvæmlega samfélagslega ábyrgt... (Viðmælandi 2 frá TM).

Pví er mikilvægt að vinna í góðri sátt og samvinnu við starfsmenn.

Ef pú ætlar að búa til og setja parna inn eitthvað sem fólki fyndist ekki vera við og sæi ekki tilganginn með poí, pá held ég að pú myndir finna mjög fljótlega fyrir poí að pað væri mjög erfitt að fá fólk til að vinna í samræmi við og svoleiðis. Pannig að ég trúi svolitið mikið á svoleiðis og að pú purfir (að) líka pegar pú ert að setja svona stefnu að vinna petta með fólkinu pannig að innleiðingin gerist um leið og pú ert að vinna að stefnunni af poí að fólk skilur og veit, meðan petta er allt að verða til, hvernig petta er hugsað og hoað er á bak við petta (Viðmælandi frá VÍS).

Jafnvel pó að viðmælendur nefni ekki sérstaklega að stærð eða smæð félaganna sé hindrun í innleiðingu samfélagslegrar ábyrgðar pá telja peir flestir að stærðin sé hindrun pegar kemur að pátttöku í alpjóðlegum samningum. Margir viðmælenda tala um að pað kalli á mikla vinnu og utanumhald sem félögin ráði ekki við.

...eins og i Global Compact pá parf náttúrulega að uppfylla skýrsluskil á hverju ári og við náttúrulega erum ekki stórfyrirtæki, pannig... (Viðmælandi frá Sjóvá)

...petta er náttúrlega rosalega umfangsmikið og gríðarlega mikið utanumhald eins og peir gera petta [Vínbúđin]. Dannig að ég er ekki viss um að við förum alla pá leið en við munum taka ákveðna stefnu í pví hvað pað er sem við viljum horfa til í pessum málum og pá halda utan um pað. Mér finnst pað svona frekar óliklegt að við förum i alla pá pætti [Global Compact] (Viðmælandi frá Verði).

\title{
6 Umræður
}

Íslensku skaðatryggingafélögin eru hvorki dæmigerð stór fyrirtæki né lítil, par sem pað fer eftir pví í hvaða samhengi pau eru skoðuð. Í fræðigreinum um samfélagsábyrgð er oftast fjallað um stór alpjóðleg fyrirtæki, sem í eðli sínu eru mjög ólík íslensku vátryggingafélögunum, m.a. hvað varðar fjölda starfsmanna og pað umhverfi sem fyrirtækin 
starfa í. Prýstingur á pessi stóru fyrirtæki um að sýna samfélagsábyrgð og birta upplýsingar um pað í formi skýrslna er nú pegar mikill (Council of the European Union, 2014) en pví er ekki fyrir að fara varðandi íslensku skaðatryggingafélögin. Síðustu árin hefur rannsóknum um samfélagsábyrgð í litlum fyrirtækjum pó fjölgað, en slíkar rannsóknir eru enn sem komið er fremur fáar (Vázquez-Carrasco og López-Pérez, 2013). Pessar rannsóknir fjalla mest um lítil fyrirtæki par sem eigendur eru oftast jafnframt lykilstjórnendur, en slíkt á ekki við um íslensku skaðatryggingafélögin. Vert er að hafa í huga að sé horft til annarra íslenskra fyrirtækja pá teljast skaðatryggingafélögin fremur stór og pví horft til peirra sem fyrirmynda pegar kemur að aðgerðum og áherslum í rekstri.

Við greiningu á samfélagsábyrgð hjá fyrirtækjum eru fjórar áhugaverðar nálganir samanber Killian, 2012 og Russo og Tencati, 2009 um pað hvernig fyrirtæki formgera samfélagsábyrgð sína. Í fyrsta lagi hvort fyrirtæki hafa sett sér skriflega stefnu. Í öðru lagi hvort skilgreint er hver ber ábyrgð á pví að fylgja henni eftir. Í priðja lagi hvort verkefni og ferlar eru vel skilgreind og í fjórða lagi hvort og pá hvernig fyrirtækin gera grein fyrir samfélagsábyrgð sinni. Pessar nálganir eru allar nátengdar fyrstu rannsóknarspurningunni sem sett var fram, p.e. Hver er stefna skaðatryggingafélaganna varðandi samfélagsábyrgð? Í viðtölunum kom fram að íslensku skaðatryggingafélögin hafa einkum stigið skref, eða áætla að stíga skref, sem snúa að fyrstu tveimur flokkunum sem fram koma hjá Killian, 2012 og Russo og Tencati, 2009. Félögin eru aftur á móti ekki komin ýkja langt í setningu og innleiðingu á samfélagsábyrgð á stefnumiðaðan hátt, en pá er miðað við að áherslur á sviði samfélagsábyrgðar séu hluti af almennri stefnumörkun fyrirtækja, áherslurnar séu sampættar kjarnastarfsemi fyrirtækja, pær taki mið af breiðum hópi hagsmunaaðila sem og skili ávinningi fyrir efnahag, samfélag og umhverfi pegar til lengri tíma er litið (Chandler og Werther, Jr., 2014). Pó má segja að að pau hafi öll unnið á einhvern hátt að verkefnum á pessu sviði, líka áður en farið var að setja á verkefni slíkan stimpil. •að virðist pó ekki vera fyrr en á árunum 2011-2013 sem félögin fara að draga hlutina saman og fjalla um verkefnin undir hatti samfélagsábyrgðar. Í dag eru félögin ýmist með skriflega stefnu varðandi samfélagsábyrgðina eða eru að móta slíka stefnu. Mælingar á árangri og birting á niðurstöðum í formi skýrslna til hagsmunaaðila eru svið par sem íslensku félögin eru ekki að fylgja peirri próun sem á sér stað hjá stærri fyrirtækjum í Evrópu og leiðandi fyrirtækjum hér á landi.

Varðandi rannsóknarspurningu tvö Hverjir eru helstu hvatar skaðatryggingafélaganna til pess að innleiða samfélagsábyrgð? pá telja viðmælendur að hvatinn til pess að setja stefnu á sviði samfélagsábyrgðar komi fyrst og fremst innanfrá, p.e. frá félögunum sjálfum en rannsóknir hafa sýnt að fólk vill frekar vinna hjá fyrirtækjum sem sýna samfélagslega ábyrgð, pað eykur starfsánægju, fyrirtækjunum helst betur á starfsmönnum og gengur betur að laða til sín hæfa starfsmenn (Renneboog o.fl., 2008). Einnig má merkja á svörum viðmælenda ytri prýsting, en vísbendingar eru um að samfélagsábyrgð hafi einnig áhrif á fjárfesta og fjármálagreinendur, jafnvel pó að rannsóknum beri ekki saman um hversu mikil áhrifin eru pegar peir meta og velja sér fjárfestingarkosti (Renneboog o.fl. 2008).

Pegar horft er til rannsóknarspurningar prjú Hverjar eru helstu áherslur skaðatryggingafélaganna við innleiðingu á samfélagsábyrgð? sést að íslensku skaðatryggingafélögin falla fremur að áherslum lítilla og meðalstórra fyrirtækja hvað samfélagsábyrgð varðar samkvæmt peim Vázqes-Carrasco og López-Pérez (sjá töflu 1). Sampætting er fremur veik, starfið ómótað og lítt formgert og nálægð við hagsmunaaðila er fremur mikil. Í ljósi stærðar íslensku félaganna er petta eðlilegt pó að ætla mætti að pau væru komin lengra í áttina að áherslum stórra fyrirtækja, samkvæmt peim Vázqes-Carrasco og López-Pérez, ef horft er til stærðar félaganna í íslensku samfélagi. Pá er ljóst að áherslur 
félaganna ná enn sem komið er til fárra pátta í kjarnastarfsemi peirra, en felast fremur í að bæta rekstur t.d. með minni pappírsnotkun eða í styrkjamálum. Hvað kjarnastarfsemina varðar pá ná aðgerðir til forvarna, en almennt ekki til vöru og pjónustu, meðhöndlunar tjóna fyrir utan raftækjaúrgang eða fjárfestinga samanber loftslagsáherslur norrænna vátryggjenda (Bosse og fleiri, 2009) eða skilgreininga á sviði samfélagsábyrgðar (Staðlaráð Íslands, 2013; Chandler og Werther, 2014). Pau geta pví gert betur og eru að vinna að pví hægt og bítandi.

Í kafla 3 voru dregin fram 6 atriði sem Rose (2013) leggur til varðandi samfélagsábyrgð tryggingafélaga og við ræðum nú pau atriði, hvert fyrir sig til að sjá hvar skaðatryggingafélögin gætu gert betur en nú er gert.

1. Rannsakendur geta ekki metið hvort skaðatryggingafélögin borgi „réttar“ bætur, par sem rannsóknin fjallaði ekki um pann pátt, né heldur nefndu viðmælendur hann í viðtölum.

2. Eins og Rose leggur til pá beita félögin sér í forvörnum og hefur sá páttur verið einn af áherslupáttum í rekstri íslenskra skaðatryggingafélaga um langt árabil, enda fara par saman fjárhagslegir hagsmunir félaganna og samfélagsábyrgð.

3. Enn sem komið er beita skaðatryggingafélögin sér lítið eða ekkert varðandi loftslagsbreytingar. Pessi páttur kom aftur á móti strax upp sem mikilvægt stefnumarkandi áhersluatriði vátryggingafélaga í Danmörku, Finnlandi, Noregi og Svípjóð í rannsókn Láru Jóhannsdóttur (2012) án pess pó að spurt væri sérstaklega um pennan pátt og byggir sú nálgun á tengslum milli öfga í veðurfari og aukinnar tjónatíðni.

4. Öll félögin taka pátt í góðgerðamálum á stefnumiðaðan hátt og velja verkefni til að styrkja sem tengjast starfseminni.

5. Lítið kom fram í rannsókninni varðandi pað að virða mannréttindi, en almennt má ætla að mannréttindi séu virt hjá íslenskum fyrirtækjum.

6. Íslensku skaðatryggingafélögin hafa ekki sett sér samfélagslega ábyrga fjárfestingastefnu. Vísbendingar eru um að pau telji að slík stefna myndi engu breyta um raunverulegar fjárfestingar, enda eru möguleikar peirra til fjárfestinga takmarkaðir, m.a. vegna lagalegra skilyrða sem og gjaldeyrishafta.

Séu upplýsingarnar dregnar saman pá má segja að skaðatryggingafélögin gætu horft nánar til kjarnastarfsemi sinnar og pess hvernig endurskoða má kjarnastarfsemi (vörur og pjónusta, tjón og forvarnir) út frá loftslagssjónarmiðum, sem og hvað ábyrgar fjárfestingar varðar.

Hver er helsti ávinningur pess að innleiða samfélagsábyrgð að mati viðmælanda? var fjórða rannsóknarspurningin. Margar ástæður geta verið fyrir pví að fyrirtæki leggi sig fram um að vera samfélagslega ábyrg. Algengt er að fyrirtæki reyni að skapa góða ímynd og að auka traust og tryggð viðskiptavina og fjárfesta við fyrirtækið eða ákveðna vöruflokka (Renneboog o.fl., 2008). Pá má nefna að áherslur á sviði umhverfisábyrgðar geta leitt til minni rekstrarkostnaður eða aukinna tekna (Hoffman, 2000). Pegar spurt var um ávinning sem hlytist af samfélagsábyrgð virtust viðmælendur sammála um að samfélagsábyrgð gæti skipt máli hvað varðar samkeppnishæfni og einnig að pannig myndu félögin líta betur út í augum fjárfesta. Ímyndarlegur ávinningur virðist pví vera sá páttur sem viðmælendur tengja helst við ávinning af innleiðingu samfélagsábyrgðar hjá skaðatryggingafélögunum.

Fimmta og síðasta rannsóknarspurningin var Hverjar eru helstu hindranir við innleiðingu á samfélagsábyrgð skaðatryggingafélaganna? Tímaskortur, forgangsröðun verkefna og skortur á skilningi eða stuðningi starfsmanna voru pau atriði sem oftast voru nefnd sem hindranir við innleiðingu samfélagsábyrgðar. Samkvæmt viðmælendum pá nota sum félögin pá skýringu 
að smæð hindri aðgerðir peirra á sviði samfélagsábyrgðar, en í pví samhengi má benda á að félögin eru stór á hérlendan mælikvarða og bera pví ábyrgð sem slík par sem horft er til peirra sem fyrirmyndar, sem og í ljósi starfseminnar sem felur m.a. í sér að lágmarka og bæta fjárahagslegt tjón.

Pekkingarleysi á málaflokknum á Íslandi hindrar líklega framgang hvað aðgerðir varðar. Í viðtölunum kemur fram mikilvægi skilnings og stuðnings starfsmanna við innleiðingu á samfélagsábyrgð, en ekki er komið inn á mikilvægan pátt sem er skuldbinding stjórnenda, sem og vitund peirra og viðhorf til samfélagsábyrgðar sem getur haft áhrif á aðgerðir eða aðgerðaleysi á sviði umhverfisábyrgðar (Lára Jóhannsdóttir, Snjólfur Ólafsson og Brynhildur Davíðsdóttir, 2013). Viðmælendur segjast horfa til fyrirtækja sem eru komin hvað lengst í samfélagsmálum hérlendis og erlendis og reyna pannig að tileinka sér málið. Í peirri vinnu leikur Festa mikilvægt hlutverk, m.a. pannig að félögin geti lært af öðrum fyrirtækjum sem komin eru lengra við að sampætta samfélagsábyrgð daglegri starfsemi, auk pess sem að starfsemi Festu hefur aukið prýsting á íslensk fyrirtæki um að vinna sýnilega að samfélagsábyrgð. Pá skiptir lagalega umhverfið einnig máli, samanber löggjöf á sviði samfélagsábyrgðar sem nú hefur verið innleidd í Evrópu (Council of the European Union, 2014) og víðar.

En hversu samfélagslega ábyrg eru íslensku skaðatryggingafélögin? Pví er vandsvarað, en tvennt er pó ljóst. Раð fyrra er að ekkert í rannsókninni gefur til kynna að skaðatryggingafélögin séu óábyrg eða standi sig illa varðandi pá pætti samfélagsábyrgðar sem pau hafa valið að leggja áherslu á, en hið seinna er að félögin eru öll að stíga sín fyrstu skref í átt að samfélagsábyrgð sé horft til skilgreininga á pví sviði (European Commission, e.d.; Staðlaráð Íslands, 2013). Pau hafa til að mynda ýmist sett stefnu um samfélagsábyrgð eða hafa pað í hyggju. Viðmælendur sjá pó enn nokkra annamarka á innleiðingu eins og fram hefur komið hér að framan, auk pess sem fram hefur komið í rannsókn að íslensku félögin eru eftirbátar skaðatryggingafélaganna á Norðurlöndum (Lára Jóhannsdóttir, 2012; 2014).

Fræðilegt gildi rannsóknarinnar felst í að varpa ljósi á viðhorf viðmælenda og pá orðræðu sem ríkjandi er í greininni um leið og hún gefur mynd af stöðu samfélagsábyrgðar hjá íslensku skaðatryggingafélögunum. Рað er mikilvægt í ljósi pess að fjármálastarfsemi, par með talið vátryggingastarfsemi, er tilgreind sem ein grunnstoð samfélagsins samkvæmt peirra eigin atvinnugreinasamtökum og pví að SFF segir að fjármálafyrirtæki beri mikla samfélagsábyrgð. Hagnýtt gildi rannsóknarinnar felst í stöðumati sem skaðatryggingafélögin geta horft til við áframhaldandi innleiðingu samfélagsábyrgðar í eigin rekstri.

Benda má á sem annmarka rannsóknarinnar að viðmælendur eru fremur fáir, en í pví samhengi er rétt að benda á að peir sem rætt var við hafa sérfræðipekkingu á sviði samfélagsábyrgðar hjá hverju félagi fyrir sig. Hvað frekari rannsóknir varðar, pá hafa rannsakendur pegar birt grein um samfélagábyrgð íslenskra viðskiptabanka, en ætlunin er að vinna að samanburðargrein á milli pessara ólíku tegunda fjármálatækifæri í náinni framtíð.

\section{Heimildir}

Ásthildur Hjaltadóttir. (2012). Mikil aukning á GRI skýrslum. Sótt af: http://festasamfelagsabyrgd.is/node/50

Berle, A. og Means, G. (1932). The Modern corporation and private property. The Macmillan Company, New York.

Blowfield, M. og Murray, A. (2014). Corporate Responsibility (3. útgáfa). Oxford University Press, Oxford. 
Bragi Skaftason. (2014). Samfélagsleg ábyrgð tryggingafélaga, siðareglur og siðferðisleg álitamál.

Óbirt BA ritgerð, Háskóli Íslands.

Bosse, S., Rasmussen, P. B., Lindenius, C., Bjerke, R., Skauge, A., og Kauppi, P.-N. (2009). Nordic insurance companies meet the challenge of climate change: Statement from the Nordic Insurance Industry. Sótt af: http://www.fnh.no/pagefiles/15970/fellesuttalelsen/pannordic\%20statement $\% 20$ on\%20climate\%20change.pdf.

Carroll, A. B. (1999). Corporate Social Responsibility: Evolution of a Definitional Construct. Business and Society, 38(3), 268-292.

Chandler, D. B. og Werther, W. B. (2014). Strategic Corporate Social Responsibility (3. útgáfa). Thousand Oaks: SAGE Publication Inc.

Christine K. J. (2012). The Impact of Financial Crisis on Corporate Social Responsibility and Its Implications for Reputation Risk Management. Journal of Management and Sustainability, 2(2), 259-275.

Council of the European Union. (2014). Press release: New transparency rules on social responsibility for big companies. Retrieved October 2, 2014, from http://www.consilium.europa.eu/uedocs/cms_data/docs/pressdata/en/intm/144945.pdf.

Creswell, J. W. (2007). Qualitative inquiry and research design: Choosing among five approaches (2 ed.). Thousand Oaks: Sage Publications, Inc.

Dagný Arnarsdóttir. (2011). „Samfélagsleg ábyrgð fyrirtækja“ Grunnlínurannsókn á CSR umræðu í íslenskum fjölmiðlum. Óbirt MS ritgerð, Háskóli Íslands.

Dagný Kaldal Leifsdóttir. (2013). Samfélagsleg ábyrgð 50 stærstu fyrirtækja Íslands; Fylgja efndir orðum? (óbirt meistararitgerð). Háskóli Íslands, Reykjavík.

Davis, K. (1973). The case for and against business assumption of social responsibilities. Academy of Management Journal, 16, 312-322.

European Commission. (2001). Corporate Social Responsibility Green paper, Promoting a European Framework for Corporate Social Responsibility. Brussel. European Commission.

European Commission. (2005). The new SME definition: User guide and model declaration EN NB-60-04-773-EN-C 92-894-7909-4. Enterprise and Industry Publications, Brussels.

European Commission. (2011). A renewed EU strategy 2011-14 for Corporate Social Responsibility. Brussel. European Commission. Sótt af: http://eurlex.europa.eu/LexUriServ/LexUriServ.do?uri=COM:2011:0681:FIN:en:PDF.

European Commission. (e.d.). Corporate Social Responsibility (CSR) in the EU. Brussel. European Commission. Sótt af: http://ec.europa.eu/enterprise/policies/sustainablebusiness/corporate-social-responsibility/index_en.htm.

Fassin, Y. (2008). SMEs and the fallacy of formalising CSR. Business Ethics: A European Review, 17:4, 364-378.

Festa-Samfélagsábyrgð fyrirtækja. (e.d. a). Um Festu. Sótt af: http://festasamfelagsabyrgd.is/um-festu.

Festa-Samfélagsábyrgð fyrirtækja. (e.d. b). Um samfélagsábyrgð. http://festasamfelagsabyrgd.is/um-samfelagsabyrgd.

Fuentes-García, F., Tablales-Núnez, J., Veroz-Herradón, R. (2008), Applicability of Corporate Social Resources Management: Perspective from Spain. Journal of Business Ethics, 82:27-44.

Global Reporting Initiative. (e.d.). What is GRI ? Sótt af: https://www.globalreporting.org/information/about-gri/what-is-GRI/Pages/default.aspx. 
Haanaes, K., Arthur, D., Balagopal, B., Kong, M. T., Reeves, M., Velken, I., et al. (2011). Sustainability: The 'Embracers' Seize Advantage. Boston: MIT Sloan Management Review and The Boston Consulting Group.

Hoffman, A. J. (2000). Competitive Environmental Strategy: A Guide to the Changing Business Landscape. Washington, D.C., Island Press.

Jamali, D., Zanhour, M. og Keshishian, T. (2009). Peculiar Strengths and Relational Attributes of SMEs in the Context of CSR. Journal of Business Ethics (2009). 87, 355-377.

Jones, D. (2012). Who cares wins: Why good business is better business. Harlow: Pearson Education Limited.

Julia Vol. (2012). Change management in financial institutions : a case study of introducing a policy on corporate social responsibility in Landsbankinn (óbirt meistararitgerð). Háskóli Íslands, Reykjavík.

Killian, S. (2012). Corporate social responsibility: A guide, with Irish experiences. Chartered accountants Ireland. Dublin.

Lára Jóhannsdóttir, Snjólfur Ólafsson og Harpa Dís Jónsdóttir. (2015). Rannsókn á samfélagsábyrgð íslenskra viðskiptabanka. Í Lára Jóhannsdóttir, Snjólfur Ólafsson \& Sveinn Agnarsson (Ritstjórar.), Vorráðstefna Viðskiptafræðistofnunar Háskóla Íslands. Reykjavík: Háskóli Î́slands, Viðskiptafræðideild, bls. 40-51.

Lára Jóhannsdóttir. (20. ágúst 2014,). Stjórnarhættir fyrirtækja, Markaðurinn, Fréttablaðið.

Lára Jóhannsdottir. (2014). The Geneva Association framework for climate change actions of insurers: A case study of Nordic insurers. Journal of Cleaner Production, 75, 20-30.

Lára Jóhannsdóttir, Snjólfur Ólafsson og Brynhildur Davíðsdóttir (2013). Stelpurnar í eldhúsinu: Viðhorf og aðgerðir á sviði umhverfismála hjá norrænum vátryggingafélögum. Samtíd, 1(2013).

Lára Jóhannsdóttir (2012). Nordic non-life insurer's interest in, and response to, environmental issues. PhD ritgerð (bls. 562). Reykjavík: Faculty of Business.

Matten, D., og Moon, J. (2008). "Implicit" and "explicit" CSR: A conceptual framework for a comparative understanding of corporate social responsibility. Academy of Management Review, 33(2), 404-424.

Rasmussen, E. S., Østergaard, P., Beckmann, S. C. (2006). Essentials of Social Science Research Methodology. Odense, University of Southern Denmark.

Renneboog, L., Horst, J.T., Zhang, C. (2008). Socially responsible investments: Institutional aspects, performance, and investor behavior. Journal of Banking \& Finance, 32(9), 1723-1742.

Rio Tinto Alcan. (2008). Alcan á Íslandi stofnaðili Epikos, miðstöðvar Íslands um samfélagsábyrgð fyrirtækja. Sótt af: http://www.riotintoalcan.is/?PageID=12\&NewsID=215.

Rose, H. (2013). How Insurance Companies Can Become Good Corporate Citizens. Risk Management, July 1st. Sótt af: http://www.rmmagazine.com/2013/07/01/how-insurancecompanies-can-become-good-corporate-citizens/.

Russo, A. og Tencati, A. (2009). Formal vs. Informal CSR Strategies: Evidence from Italian Micro, Small, Medium-sized, and Large Firms. Journal of Business Ethics, 85, 339-353.

Samtök fjármálafyrirtækja (e.d. a). SFF. Sótt af: http://sff.is/samtok-fjarmalafyrirtaekja/sff.

Samtök fjármálafyrirtækja (e.d. b). Siðferðisviðmið á fjármálamarkaði. Sótt af: http://sff.is/samtokfjarmalafyrirtaekja/sidferdisvidmid-fjarmalamarkadi.

Samtök fjármálafyrirtækja. (e.d. c). Flokkar vátrygginga. Sótt 20. október 2014 af http://sff.is/malaflokkar/vatryggingastarfsemi/flokkar-vatrygginga.

Santos, M. (2011). CSR in SMEs: strategies, practices, motivations and obstacles. Social Responsibility Journal 7(3), $490-508$. 
Sjóvá. (2012). Ársskýrsla 2011. Sótt 19. nóvember 2014 af https://www.sjova.is/files/2012_3_27_arsskyrsla_2011_stakar_sidur.pdf.

Snjólfur Ólafsson, Brynhildur Davíðsdóttir og Lára Jóhannsdóttir. (2014). Samfélagsábyrgð íslenskra fyrirtækja. Í Auður Hermannsdóttir, Ester Gústavsdóttir og Kári Kristinsson (ritstj.) Vorráðstefna Viðskiptafræðistofnunar Háskóla Íslands, 14. mars 2010, bls. 139-148. Staðlaráð Íslands. (2013). Leiðbeiningar um samfélagslega ábyrgð, ÍST, ISO 26000:2010, 1. útgáfa 2010, 11-01.

Strauss, A., Corbin, J. (1998) Basics of Qualitative Research, Techniques and Procedures for Developing Grounded Theory. (2. útgáfa). United States of America: Sage Publications, Inc.

Taylor, S. J. og Bogdan, R. (1998). Introduction to qualitative research methods: a guidebook and resource. (3. útgáfa). New York: John Wiley \& Sons.

UNEP Finance Initiative. (e.d.). What we do. Sótt pann 17. nóvember 2014 af: http://www.unepfi.org/.

United Nations Global Compact. (e.d.). Overview of the UN Global Compact. Sótt af: https://www.unglobalcompact.org/AboutTheGC/index.html.

UN Women á Íslandi. (e.d.). Jafnréttissáttmáli UN Women. Sótt 19. nóvember 2014 af https://www.unwomen.is/index.php/innlend-verkefni/jafnrettissattmali-un-women

VÍS. (e.d. a). Samfélagsábyrgð VÍS. Sótt af: https://www.vis.is/umvis/samfelagsabyrgd/.

VÍS. (e.d. b). Mannauður VÍS. Sótt 19. nóvember 2014 af http://vis.is/umvis/samfelagsabyrgd/mannaudur/.

VÍS. (e.d. c.) Stjórnarhættir VÍS. Sótt 21. nóvember 2014 af: https://www.vis.is/umvis/samfelagsabyrgd/stjornarhaettir/

VÍS. (2012). Ársskýrsla 2011. Sótt 19. nóvember 2014 af https://www.vis.is/library/Fjarfestingatengsl/Fjarhagsupplysingar/vis_arsskyrsla2011_ve fur.pdf.

Vázquez-Carrasco, R. og López-Pérez, M.E. (2013). Small \& medium-sized enterprises and Corporate Social Responsibility: a systematic review of the literature. Quality and Quantity. 47, 3205-3218.

Viðskiptablaðið. (2014). Vörður hlýtur jafnlaunavottun VR. Sótt 19. nóvember 2014 af http://www.vb.is/frettir/102843/.

VR. (2014) Sjóvá fær jafnlaunavottun. Sótt 21. nóvember 2014 af http://www.vr.is/frettir/lesafrett/2014/05/14/Sjova-faer-Jafnlaunavottun-VR/?hidedate=false

Vörður. (2014). Vörður fær jafnlaunavottun VR fyrst fjármálafyrirtækja. Sótt 21. nóvmeber 2014 af http://www.vordur.is/Um-Vord/thjonusta/frettir/nanar/320/vordur-tryggingar-hlyturjafnlaunavottun-vr-fyrst-fjarmalafyrirtaekja

Zandvliet, R. (2011). Corporate Social Responsibility Reporting in the European Union: Towards a more Univocal Framework. The Columbia Journal of European Law. 18 column. J.Eur. L. F. 38. Sótt af: http://www.cjel.net/online/18_1-zandvliet/. 